\title{
OPTIMALISASI KEBIJAKAN DISEMINASI INFORMASI KINERJA LEMBAGA LEGISLATIF DAERAH DALAM PENINGKATAN KUALITAS DEMOKRASI
}

\author{
Mahi M. Hikmat \\ Pascasarjana Universitas Islam Negeri Sunan Gunung Djati Bandung, Dosen Program Studi Ilmu \\ Komunikasi Fakultas Ilmu Sosial dan Ilmu Politik Universitas Komputer Indonesia \\ Jalan Dipati Ukur Bandung \\ email-mmhikmat@yahoo.co.id
}

\begin{abstract}
One of the paradigm changes which inherent from the birth of local autonomy policy is strengthening the accessibility of the people to the policies of the government made by local government. It occurred in strengthening existence of local representative (DPRD) as representatives of the will of the people. As the mandate of article 18 paragraph ( 3 ) 1945 constitution, local representative was elected through general election by local people, that the voice of local representative is the voice of the local people.

Information dissemination of local legislative performance becomes really important part in strengthening parliament. To uncover the purpose of juridical, the study was conducted with the use of subjective approach and a method of descriptive qualitative study.

This study finds several conclusions, 1) Many laws relating to the legislative institutions gives urgency disseminate information performance as part of accountability public and an essential part of strengthening the quality of democracy in the local area; 2) All activities implementation of legislation relating to the function, responsibility and authority, rights and obligations, are crucial to be disseminated to the public, except for information which should be confidential according to legislation; 3) Model of alternative disseminate information performance is a persuasion model of Hugh Rank, which more strengthens the principal engagement, exposes intensively ideas, events, activity or other substance of information dissemination which is good and excess (the positive side) and which plays, disguises, or downplays the negative sides.
\end{abstract}

Keywords: Information, Dissemination, Performance, DPRD, The People

\begin{abstract}
Abstrak
Salah satu perubahan paradigma yang mendasar dari lahirnya kebijakan otonomi daerah adalah penguatan aksebilitas rakyat terhadap kebijakan yang dibuat Pemerintah Daerah. Hal itu diwujudkan dengan penguatan eksistensi DPRD (Dewan Perwakilan Rakyat Daerah) sebagai representasi kehendak rakyat. Sebagaimana amanah Pasal 18 ayat (3) UUD 1945, DPRD dipilih melalui Pemilu oleh rakyat daerah, sehingga suara DPRD merupakan suara rakyat daerah.

Diseminasi informasi kinerja Legislatif Daerah merupakan bagian yang sangat penting dalam penguatan DPRD, sehingga harus dioptimalkan dalam kerangka mendorong kualitas demokrasi di daerah. Untuk mengungkap tujuan tersebut dilakukan kajian yuridis dengan menggunakan pendekatan subyektif dan metode deskriptif kualitatif.

Kajian ini menghasilkan kesimpulan, 1). Banyak peraturan perundangan yang terkait dengan lembaga Legislatif Daerah mengamanahkan urgensi diseminasi informasi kinerja sebagai bagian dari pertanggungjawaban publik dan merupakan bagian penting dari penguatan kualitas demokrasi di daerah; 2). Semua kegiatan dalam implementasi amanah peraturan perundangan terkait dengan fungsi, tugas dan wewenang, hak dan kewajiban, merupakan hal penting untuk didiseminasikan kepada publik, kecuali informasi yang harus dirahasiakan menurut peraturan perundangan; 3) Model alternatif diseminasi informasi kinerja adalah Model Persuasi Hugh Rank yang lebih menguatkan pelibatan komponen pokok, mengekspose secara intensif ide-ide, peristiwa, kegiatan atau substansi diseminasi informasi lainnya yang bernilai kebaikan dan kelebihan (sisi positif) serta memainkan, menyamarkan, atau menyembunyikan (downplay) aspek-aspek sisi negatif.
\end{abstract}

Kata Kunci : Diseminasi, Informasi, Kinerja, DPRD, Rakyat 


\section{Pendahuluan}

Salah satu perubahan paradigma yang mendasar dari lahirnya kebijakan otonomi daerah adalah penguatan aksebilitas rakyat terhadap kebijakan yang dibuat oleh Pemerintah Daerah. Hal itu diwujudkan dengan penguatan terhadap eksistensi DPRD (Dewan Perwakilan Rakyat Daerah) sebagai representasi kehendak rakyat. Sebagaimana amanah Pasal 18 ayat (3) Undang-Undang Dasar 1945 bahwa DPRD dipilih melalui Pemilu oleh rakyat daerah, sehingga suara DPRD merupakan suara rakyat daerah.

Undang-Undang Pemerintahan Daerah dengan tegas menyatakan bahwa posisi DPRD dalam Pemerintahan di Daerah cukup kuat sebagai partner kerja bagi Kepala Daerah. Yang dimaksud Pemerintahan Daerah adalah Pemerintah Daerah dan DPRD.

Iklim politik otonomi daerah seperti itu, memberikan keleluasaan kepada DPRD untuk menjalankan fungsinya, baik fungsi legislasi, anggaran, maupun pengawasan yang merupakan representasi rakyat di provinsi.

Adanya representasi rakyat menunjukkan benang merah aksebilitas rakyat daerah dengan DPRD setelah pemilihannya pun melalui Pemilu. Selain itu, hal itu pun menyadarkan bahwa DPRD adalah lembaga demokratis yang lahir dari proses demokratis, sehingga kinerja dan pertanggungjawabannya pun harus melalui proses yang sama.

Oleh karena itu, UU Pemda pun dengan tegas menyebutkan kewajiban DPRD dalam kerangka merepresentasikan kehendak rakyat daerah, di antaranya, memperjuangkan peningkatan kesejahteraan rakyat, menyerap dan menghimpun aspirasi konstituen melalui kunjungan kerja secara bekala, menampung dan menindaklanjuti aspirasi dan pengaduan masyarakat, serta memberikan pertanggungjawaban secara moral dan politis kepada konstituen di daerah pemilihan.

Dalam konteks tersebutlah DPRD selain harus merespresentasikan kehendak rakyat juga harus melakukan komunikasi politik yang intens dengan rakyat, termasuk mempertanggungjawabkan kinerjanya kepada rakyat. Sebagai salah satu bentuk pertanggungjawaban DPRD terhadap rakyat adalah memberikan informasi yang jelas atas segala hal yang dilakukannya terhadap rakyat. Dalam konteks ini, diseminasi informasi kinerja DPRD merupakan bagian yang sangat penting guna membangun komunikasi yang sehat di antara DPRD dengan rakyat yang diwakilinya.

Selain itu, diseminasi informasi kinerja DPRD pun memberikan kesempatan kepada rakyat untuk turut serta berpartisipasi kepada DPRD dalam berbagai bentuk, di antaranya pengawasan. Dengan mendapatkan informasi yang jelas, rakyat daerah dapat memonitor berbagai hal terkait kinerja DPRD apakah sudah sesuai dengan representasi rakyat daerah.

Komunikasi yang sehat seperti itulah yang sejatinya dibangun dalam negara demokrasi. Rakyat memilih DPRD; DPRD bekerja untuk rakyat, sehingga DPRD harus mempertanggungjawabkannya kepada rakyat melalui diseminasi informasi kinerja, sehingga rakyat pun dapat memberikan apresiasi atas kinerja bagus DPRD atau memberikan saran dan masukan jika masih terdapat kinerja yang belum optimal.

Kondisi seperti itulah yang seharusnya terjadi sebagaimana makna utama demokrasi: dari rakyat, oleh rakyat, dan untuk rakyat yang dalam lembaga negara di daerah diwakili oleh DPRD. Sebagaimana kewajiban lain dari DPRD adalah menaati prinsip demokrasi dalam penyelenggaraan pemerintahan daerah.

Oleh karena itu, membuka aksebilitas rakyat terhadap DPRD melalui diseminasi informasi kinerja lembaga legislatif daerah merupakan bagian dari upaya meningkatkan kualitas demokrasi sebagaimana prinsip demokrasi di antaranya adalah transparansi. Dalam hal inilah, optimalisasi diseminasi informasi kinerja lembaga legislatif daerah menjadi sangat penting dan sebagai salah satu upaya meningkatkan kualitas demokrasi di daerah. 
Diseminasi informasi kinerja lembaga Legislatif Daerah merupakan bagian yang sangat penting dalam penguatan kelembagaan DPRD. Hal itu dapat tergambarkan dari pernyataan masalah berikut:

1. Diseminasi informasi kinerja Lembaga Legislatif Daerah merupakan bagian dari transparansi sebagai salah satu prinsip demokrasi, sehingga penguatan diseminasi informasi kinerja akan berdampak pada penguatan implementasi demokrasi;

2. Diseminasi informasi kinerja Lembaga Legislatif Daerah merupakan bagian dari amanah peraturan perundangundangan terkait fungsi dan kewajiban DPRD, sehingga harus dilakukan oleh DPRD;

3. Diseminasi informasi kinerja Lembaga Legislatif Daerah merupakan bagian dari komunikasi politik yang sehat dalam membangun sinergisitas DPRD dengan rakyat pemilihnya;

4. Diseminasi informasi kinerja Lembaga Legislatif Daerah sebagai salah satu bentuk pertanggungjawaban DPRD terhadap konstituennya: rakyat daerah;

5. Diseminasi informasi kinerja Lembaga Legislatif Daerah sebagai sarana aktualisasi DPRD dalam menunjukkan prestasinya di mata publik pemilihnya;

6. Diseminasi informasi kinerja lembaga Legislatif Daerah terkalahkan oleh diseminasi informasi lembaga Legislatif Pusat;

7. Media massa, terutama media massa nasional, lebih konsen pada diseminasi informasi lembaga Legislatif Pusat ketimbang lembaga Legislatif Daerah;

8. Lembaga Legislatif Daerah belum optimal dalam melakukan diseminasi informasi dan lebih fokus pada model komunikasi linear.

Berdasarkan pernyataan permasalahan tersebut, maka dapat dirumuskan maksud Kajian Optimalisasi Kebijakan Diseminasi Informasi Kinerja Lembaga Legislatif Daerah dalam Peningkatan Kualitas Demokrasi adalah untuk menguatkan eksistensi Lembaga Legislatif Daerah dalam pertanggungjawaban publik sebagai salah satu parameter peningkatan kualitas demokrasi .

Adapun tujuan kegiatan Kajian Optimalisasi Kebijakan Diseminasi Informasi Kinerja Lembaga Legislatif Daerah dalam Peningkatan Kualitas Demokrasi sebagai berikut: 1. Mendeskripsikan dan menganalisa peraturan perundang-undangan dan kebijakan diseminasi informasi kinerja Lembaga Legislatif Daerah dalam peningkatan kualitas demokrasi; 2. Merumuskan model diseminasi informasi kinerja Lembaga Legislatif Daerah sebagai wujud pertanggungjawaban publik dalam optimalisasi peningkatan kualitas demokrasi.

Kajian ini menggunakan pendekatan kualitatif dengan metode yang digunakan adalah metode deskriptif. Penelitian deskriptif merupakan metode penelitian yang berusaha menggambarkan dan menginterpretasi objek sesuai dengan apa adanya. Data yang dikumpulkan berupa kata-kata, gambar, dan bukan angka-angka, sehingga laporan penelitian akan berisi kutipan-kutipan data untuk memberikan gambaran penyajian laporan tersebut. Analisis data yang dilakukan adalah analisis data induktif melalui proses penyederhanaan data ke dalam bentuk yang lebih mudah dibaca dan diinterpretasikan. Secara implementatif, dalam kajian ini dilakukan pendekatan perundang-undangan (Statuta Approach) dan jenis penelitian hukum normative dengan sumber data peraturan perundang-undangan yang terkait dengan judul kajian.

\section{Pembahasan}

\section{Urgensi Diseminasi Informasi bagi Legilatif Daerah}

Sebagai Badan Publik, DPRD harus mengimplementasikan keterbukaan informasi publik. Sebagai lembaga Legislatif Daerah yang para anggotanya dipilih melalui Pemilu, harus membuka diri selebar-lebarnya terhadap 
akses rakyat. Sebagai lembaga perwakilan rakyat daerah, DPRD harus mempertanggungjawabkan segala kegiatannya kepada seluruh rakyat daerah. Oleh karena itu, diseminasi informasi kinerja lembaga legislatif daerah merupakan hal yang sangat urgen dilakukan DPRD. Hal itu merupakan perwujudan dari eksistensi DPRD sebagai representasi kehendak rakyat. Sebagaimana amanah Pasal 18 ayat (3) Undang-Undang Dasar 1945 bahwa DPRD dipilih melalui Pemilihan Umum oleh rakyat daerah, sehingga suara DPRD merupakan suara rakyat daerah.

Realitas para anggota DPRD dipilih melalui Pemilu mengisyaratkan bahwa demokratisasi dalam pengelolaan pemerintahan tidak hanya terjadi pada Pemerintahan Pusat, tetapi juga dalam penyelenggaraan pemerintahan di daerah. Penyelenggaraan Pemerintahan di daerah tidak hanya didominasi lembaga eksektif daerah, tetapi juga wajib menyertakan lembaga legislatif daerah. Hal itu menunjukkan implementasi demokratisasi kerakyatan karena pihak-pihak yang diberikan hak dan kewajiban dalam pengelolaan pemerintahan di daerah merupakan hasil pilihan rakyat daerah. Kepala daerah dan wakil kepala daerah dipilih secara langsung melalui Pemilihan Kepala Daerah Langsung dan DPRD pun dipilih melalui pemilihan umum.

Penyelenggaraan pemerintahan yang seperti itulah yang mengarah pada perwujudan cita-cita demokrasi tertinggi, yakni menyelenggarakan pemerintahan dari rakyat, oleh rakyat, dan untuk rakyat sebagaimana jargon yang disampaikan Presiden Amerika Serikan Abraham Lincoln (1861-1865). Dalam konteks ke-Indonesiaan, konsepsi penguatan pengelolaan pemerintahan daerah dari rakyat, oleh rakyat, dan untuk rakyat selain diamanahkan dalam konstitusi negara (UUD 1945) dan diimplementasikan dengan menyeimbangkan kekuasaan eksekutif dengan legislatif yang keduanya merupakan representasi suara rakyat; kepala daerah dan DPRD dipilih secara langsung oleh rakyat daerah, menurut pendiri Republik Indonesia, Mohammad Hatta, sebagai upaya mengkikis kekuasaan raja yang absolut oleh kedaulan rakyat yang diwakilkan.

Sebagaimana secara teoretis Benyamin Barber menyebutkan tentang konsepsi demokrasi partisipatoris yang dipandangnya sebagai demokrasi tertinggi karena lebih mengunggulkan aksebilitas dan partisipasi rakyat. Nilai-nilai demokrasi seperti selfgovernment, persamaan/kesetaraan politik, dan reasoned rule ditekankan pada partisipasi seluruh warga negara (daerah) secara langsung dalam pengambilan keputusan. Demokrasi partisipatoris berpandangan bahwa para warga negara berinteraksi secara langsung dalam membahas pilihan berbagai kebijakan untuk mengantisipasi permasalahan yang mereka hadapi bersama.

Wujud nyata dari demokrasi partisipatoris adalah diselenggarakanya Pemilihan Umum untuk menentukan para penyelenggara pemerintahan, baik di pusat maupun di daerah. Orang-orang yang terpilih melalui proses Pemilihan Umumlah yang pada akhirnya diserahi kedaulatan rakyat untuk menyelenggarakan pemerintahan.

Sebagaimana amanah Pasal 1 UUD 1945 yang menyatakan bahwa kedaulatan berada di tangan rakyat dan dilaksanakan melalui Undang-Undang Dasar ataupun UndangUndang. Undang-Undang Dasar 1945 mengamanahkan DPRD (lembaga legislatif daerah) dipilih melalui Pemilihan Umum.

Pemilihan Umum adalah sarana pelaksanaan kedaulatan rakyat yang dilaksanakan secara langsung, umum, bebas, rahasia, jujur, dan adil dalam Negara Kesatuan Republik Indonesia berdasarkan Pancasila dan Undang-Undang Dasar $1945^{1}$. Pemilihan Umum yang berlalu dan diselenggarakan di Indonesia terdapat tiga, yakni Pemilihan Umum untuk memilih

1. Undang-Undang No. 8 Tahun 2012 tentang Pemilu 
anggota legislatif yang di antaranya untuk memilih anggota DPRD; Pemilihan Umum untuk memilih kepala daerah dan wakil kepala daerah, dan Pemilihan Umum untuk memilih Presiden dan Wakil Presiden.

Tindak lanjut dari Pemilihan Umum dalam menuju demokrasi partisipatoris adalah memberikan penguatan pada akses dan peluang keterlibatan rakyat tidak hanya dalam proses rekruitment politik lokal, tetapi juga pada pembuatan kebijakan publik di daerah. Hal itu perlu terus dipupuk karena berdasarkan pengalaman historis masa lalu, eksistensi DPRD sebagai lembaga legislatif daerah mengalami pasang surut sejalan dengan berubah-ubahnya kebijakan.

Secara bertahap, baik dalam UUD 1945 yang telah mengalami empat kali amandemen, maupun undang-undang yang mengatur Pemerintahan Daerah yang berganti berkalikali, eksistensi DPRD sebagai lembaga legislatif daerah mengalami perubahan yang signifikan. Sebelumnya domain atau ranah kebijakan publik di daerah hanya dikuasai kalangan terbatas, terutama eksekutif daerah. Namun, pemberlakuan kebijakan desentralisasi telah mendorong penguatan lembaga legislatif daerah dan keterlibatan rakyat yang meluas dalam ranah kebijakan publik daerah. Inilah yang dimaksud bahwa upaya mewujudkan demokrasi partisipatoris telah menjadi bagian visi, misi, dan program pengelolaan dan penyelenggaraan pemerintahan di daerah.

Undang-Undang Pemerintahan Daerah dengan tegas menyatakan bahwa posisi DPRD dalam Pemerintahan di Daerah cukup kuat sebagai partner kerja bagi Kepala Daerah. Yang dimaksud Pemerintahan Daerah adalah Pemerintah Daerah dan DPRD. DPRD mempunyai hak untuk meminta pertanggungjawaban kepala daerah pada akhir tahun anggaran, pada akhir masa jabatan, atau bisa terjadi kasus-kasus tertentu. Dengan ketentuan itu, seorang kepala daerah wajib membuat Laporan Pertanggungjawaban (LPJ) kepada DPRD. Hak yang dimiliki DPRD ini dimaksudkan sebagai mekanisme checks dan balanced terhadap pihak eksekutif daerah. Dengan mekanisme ini, kinerja pemerintah daerah dapat dinilai secara teratur dan mendapat kontrol DPRD.

Iklim politik otonomi daerah seperti itu, memberikan keleluasaan kepada DPRD untuk menjalankan fungsinya: a legislasi, b. anggaran, dan c. pengawasan. Ketiga fungsi tersebut dijalankan dalam kerangka representasi rakyat di provinsi.

Adanya representasi rakyat menunjukkan benang merah aksebilitas rakyat daerah dengan DPRD setelah pemilihannya pun dilakukan melalui Pemilu. Selain itu, pasalpasal tersebut pun makin menyadarkan bahwa DPRD adalah lembaga demokratis yang lahir dari proses demokratis, sehingga kinerja dan pertanggungjawabannya pun harus melalui proses yang sama. Tidak hanya kepala daerah sebagai eksekutif daerah yang harus mempertanggungjawabkan kinerjanya melalui LPJ kepada DPRD, tetapi DPRD pun harus mempertanggungjawabkannya kepada rakyat daerah.

Oleh karena itu, beberapa point dalam UU Pemerintah Daerah dengan tegas menyebutkan kewajiban DPRD dalam kerangka merepresentasikan kehendak rakyat daerah. Di antara point dalam pasal tersebut: memperjuangkan peningkatan kesejahteraan rakyat, menyerap dan menghimpun aspirasi konstituen melalui kunjungan kerja secara bekala, menampung dan menindaklanjuti aspirasi dan pengaduan masyarakat, serta memberikan pertanggungjawaban secara moral dan politis kepada konstituen di daerah pemilihan.

Dalam konteks tersebutlah DPRD selain harus merespresentasikan kehendak rakyat juga harus melakukan komunikasi politik yang intens dengan rakyat, termasuk mempertanggungjawabkan kinerjanya kepada rakyat. Sebagai salah satu bentuk pertanggungjawaban DPRD terhadap rakyat adalah memberikan informasi yang jelas atas segala hal yang dilakukannya terhadap rakyat. Dalam konteks ini, diseminasi informasi kinerja DPRD merupakan bagian yang sangat 
penting guna membangun komunikasi yang sehat di antara DPRD dengan rakyat yang diwakilinya.

Apalagi Undang-Undang No. 14 tahun 2008 tentang Keterbukaan Informasi Publik dengan tegas menyebutkan bahwa salah satu Badan Publik yang memiliki kewajiban untuk mengimplementasikan Keterbukaan Informasi Publik adalah lembaga Legislatif, termasuk legislatif daerah. Badan Publik adalah lembaga eksekutif, legislatif, yudikatif, dan badan lain yang fungsi dan tugas pokoknya berkaitan dengan penyelenggaraan negara, yang sebagian atau seluruh dananya bersumber dari Anggaran Pendapatan dan Belanja Negara dan/atau Anggaran Pendapatan dan Belanja Daerah, atau organisasi nonpemerintah sepanjang sebagian atau seluruh dananya bersumber dari Anggaran Pendapatan dan Belanja Negara dan/atau Anggaran Pendapatan dan Belanja Daerah, sumbangan masyarakat, dan/atau luar negeri ${ }^{2}$.

Sebagai lembaga legislatif daerah, DPRD harus mengimplementasikan Keterbukaan Informasi Publik. Seluruh informasi yang dihasilkan, disimpan, dikelola, dikirim, dan/atau diterima oleh DPRD yang berkaitan dengan penyelenggara dan penyelenggaraan negara dan/atau penyelenggara dan penyelenggaraan badan publik lainnya yang sesuai dengan Undang-Undang serta informasi lain yang berkaitan dengan kepentingan publik wajib disampaikan kepada publik melalui sarana publikasi seperti web site, papan pengumuman, dan lain sebagainya ${ }^{3}$.

DPRD harus memiliki kebijakan untuk melakukan diseminasi informasi dengan menyediakan, memberikan dan/atau menerbitkan Informasi Publik yang berada di bawah kewenangannya kepada Pemohon Informasi Publik, selain informasi yang

2. Angka 3 Undang-Undang No. 14 tahun 2008 tentang Keterbukaan Informasi Publik

3. Angka 2 Undang-Undang No. 14 tahun 2008 tentang Keterbukaan Informasi Publik dikecualikan sesuai dengan ketentuan; menyediakan Informasi Publik yang akurat, benar, dan tidak menyesatkan; membangun dan mengembangkan sistem informasi dan dokumentasi untuk mengelola Informasi publik secara baik dan efisien sehingga dapat diakses dengan mudah; membuat pertimbangan secara tertulis setiap kebijakan yang diambil untuk memenuhi hak setiap orang atas Informasi Publik dengan memanfaatkan sarana dan/atau media elektronik dan nonelektronik ${ }^{4}$.

Sebagai Badan Publik, DPRD wajib mengumumkan informasi melalui pengumuman. Informasi yang wajib diumumkan DPRD sebagai Badan Publik negara adalah informasi yang wajib disediakan dan diumumkan secara berkala sekurang-kurangnya melalui situs resmi dan papan pengumuman dengan cara yang mudah diakses oleh masyarakat. Pengumuman informasi itulah yang dalam istilah lain adalah diseminasi informasi: DPRD wajib melakukan diseminasi informasi.

Secara sederhana diseminasi informasi dapat diartikan sebagai penyebaran informasi kepada masyarakat. Tujuan diseminasi informasi untuk membantu masyarakat mendapatkan informasi, sehingga terdorong terjadinya perubahan, sikap dan perilaku ke arah yang lebih baik. Diseminasi informasi suatu kegiatan yang ditujukan kepada suatu kelompok target atau individu agar masyarakat memperoleh informasi, timbul kesadaran, menerima, dan akhirnya memanfaatkan informasi tersebut ${ }^{5}$.

Selain diseminasi informasi yang diamanahkan Undang-Undang Keterbukaan Informasi Publik, sebagai bentuk pertanggungjawaban DPRD kepada rakyat pemilihnya yang harus didesiminasikan

4. Pasal 7 Undang-Undang No. 14 tahun 2008 tentang Keterbukaan Informasi Publik

5. http://www.pdii.lipi.go.id/2011/09/21: Pendekatan Informasi sebagai Komuditi dalam Proses Diseminasi Informasi 
adalah informasi tentang kinerja DPRD. DPRD harus menyebarkan informasi segala hal yang dikerjakan sebagai wakil rakyat dalam menjalankan fungsi legislasi, anggaran, maupun fungsi pengawasan melalui berbagai jenis media, selain web site dan papan pengumuman dapat juga melalui buku, majalah, surat kabar, film, televisi, musik, game, dan sarana diseminasi lainnya dengan berbagai strategi.

Diseminasi melalui konferensi pers, merupakan kegiatan yang dilakukan dengan mengundang wartawan dari sejumlah media cetak, TV, radio dan media online ke suatu tempat yang ditentukan dan menghadirkan satu atau beberapa nara sumber untuk memberikan keterangan atau pernyataan sehubungan dengan isu yang akan disampaikan.

Diseminasi melalui wawancara pers, merupakan kegiatan yang dilakukan dengan mengundang wartawan dari salah satu media cetak atau elektronik, atau media online ke suatu tempat dimana satu orang nara sumber dihadirkan untuk diwawancari. Hasil wawancara tersebut kemudian dimuat sebagai berita dalam media.

Diseminasi melalui penulisan artikel, yaitu membuat tulisan mengenai suatu topik untuk dimuat dalam sebuah jurnal ilmiah atau bulletin yang diterbitkan sendiri atau instansi, lembaga, organisasi lain; atau dikirim ke redaksi suatu penerbitan media cetak.

Diseminasi melalui publikasi adalah membuat barang cetakan seperti poster, flier, brosur, leaflet, dan lain-lain; lalu disebarkan kepada publik atau ditempatkan pada papan informasi yang tersedia di suatu instansi.

Diseminasi melalui dialog atau talk show, yaitu kegiatan penayangan acara perbincangan dan tanya jawab dengan suatu topik melalui televisi atau radio dengan menampilkan beberapa orang ahli sebagai nara sumber

Diseminasi informasi kinerja DPRD pun memberikan kesempatan kepada rakyat untuk turut serta berpartisipasi kepada DPRD dalam berbagai bentuk, di antaranya pengawasan.
Dengan mendapatkan informasi yang jelas, rakyat daerah dapat memonitor berbagai hal terkait kinerja DPRD apakah sudah sesuai dengan representasi rakyat daerah. Sebagai parameter kinerja DPRD, UU Pemerintahan Daerah memberikan rujukan dalam bentuk tugas dan wewenang, hak, dan kewajiban anggota DPRD. Implementasi dari tugas, wewenang, hak, dan kewajiban adalah kinerja DPRD yang seharusnya didiseminasikan secara optimal, sehingga rakyat tahu, paham, dan memberikan apresiasi, baik dalam bentuk pengakuan atas eksistensi dan prestasi DPRD maupun dalam bentuk partisipasi dengan memberikan kritik, saran, dan masukan guna penguatan kinerja DPRD.

Selain itu, diseminasi informasi juga merupakan upaya ekspose intensif dalam kerangka mengungkap informasi kebaikankebaikan dan kelebihan-kelebihan (sisi positif) dari lembaga legislatif daerah pada benak publik sebagai persuader. Hal itu sangat penting dilakukan oleh DPRD pada era ini ketika publik/rakyat lebih konsen pada kinerja DPR (pusat) dan mengabaikan, bahkan menganggap "mandul" terhadap DPRD. Perhatian rakyat ini dapat tergambar dari dominasi diseminasi informasi kinerja DPR melalui media massa, terutama televisi. Derasnya diseminasi informasi DPR, terlepas dari substansi informasi kebaikan dan kekurangan, telah menyisihkan diseminasi informasi DPRD. Oleh karena itu, jika DPRD menganggap bahwa diseminasi informasi kinerja lembaga eksekutif daerah tidak penting, bahkan cenderung ketakutan karena bercermin pada lebih dominannya informasi kekurangan ketimbang kebaikan, maka eksistensi DPRD akan makin tenggelam.

Padahal, sebagaimana eksistensi DPRD Provinsi Jawa Barat yang tercatat memiliki prestasi memadai sejalan dengan prestasi Pemerintah Propinsi Jawa Barat, misalnya, dalam menjalankan fungsi anggaran, sehingga hasil pemeriksaan BPK menyatakan pengelolaan anggaran di Pemerintahan Daerah Provinsi Jawa Barat WTP (Wajar Tanpa Pengecualian); Dalam hal fungsi 
legislasi, Pemerintahan Provinsi Jawa Barat pun tercatan dalam periode DPRD 2009-2014 menghasilan Peraturan Daerah yang "gemuk", dapat membangun gedung DPRD Jawa Barat yang mandiri, dan sejumlah prestasi lainnya. Namun, seluruh informasi tentang prestasi DPRD Jawa Barat tersebut tidak banyak diketahui rakyat Jawa Barat karena melimpahnya informasi DPR Pusat dan diseminasi internal yang dilakukan DPRD Jawa Barat pun diindikasikan belum optimal.

Jika diseminasi informasi kinerja DPRD optimal, terutama dalam menggalang informasi tentang kebaikan-kebaikan dan halhal positif yang dilakukan DPRD, berdampak pula pada tumbuhnya citra positif bagi kelembagaan DPRD yang berimbas juga pada citra positif Pemerintahan Daerah. Citra terbentuk dari panduan antara informasi dan pengalaman. Informasi yang ada atau diterima oleh rakyat mengenai DPRD akan membentuk citra DPRD sekaligus dapat juga mengangkat citra positif pada kualitas demokrasi di daerah karena rakyat sering menakar kualitas demokrasi itu dari kualitas kinerja lembaga demokrasi seperti DPRD.

Bangunan penyelenggaraan pemerintahan dari rakyat, oleh rakyat, dan untuk rakyat sebagaimana jargon demokrasi dapat diwujudkan dengan diseminasi informasi kinerja lembaga legislatif daerah secara aktif dalam bingkai strategi komunikasi berbasis linear, tetapi transaksional partisipatoris. DPRD sebagai sumber informasi sehingga dengan diseminasi informasi kinerja dapat memberikan stimulus positif bagi lahirnya respon yang menunjukkan tumbuhnya tingkat partisipasi rakyat daerah terhadap kebijakankebijakan dalam pengelolaan Pemerintahan Daerah.

Kondisi seperti itulah yang seharusnya terjadi sebagaimana makna utama demokrasi: dari rakyat, oleh rakyat, dan untuk rakyat yang dalam lembaga negara di daerah diwakili oleh DPRD. Sebagaimana kewajiban lain dari DPRD dalam peraturan perundangundangan.

\section{Strategi dan Model Diseminasi Kinerja Legislatif Daerah}

Kendati urgensinya sangat tinggi dan substansinya sangat banyak, diseminasi informasi kinerja DPRD tetap tidak mudah untuk dilaksanakan; memerlukan strategi yang tepat, sehingga efek yang dihasilkan akan sesuai dengan harapan dan jauh dari lahirnya kesalahpahaman. Sebagai institusi politik, diseminasi informasi yang harus dikembangkan DPRD harus berangkat dari enam tujuan.

Pertama mengangkat citra (image) positif kelembagaan. Citra adalah gambaran seseorang/lembaga yang tersusun melalui persepsi yang bermakna melalui kepercayaan, nilai, dan harapan (Hikmat,2010:39). Menurut Dan Nimmo (2000:6), citra politik terjalin melalui pikiran dan perasaan secara subyektif yang akan memberikan penilaian serta pemahanan terhadap peristiwa politik tertentu.

Kedua membangun pendapat umum atau public opinion yang merupakan sikap rakyat terhadap suatu masalah yang menyangkut kepentingan umum. Sikap ini akan lahir dari berbagai upaya kelembagaan dengan menggunakan media umum, baik media modern maupun tradisional.

Ketiga menumbuhkan partisipasi politik pada rakyat. Partisipasi politik sebagai perhatian dari warga yang berupaya menyampaikan kepentingan-kepentingan terhadap pejabat publik. Miriam Budiardjo (1995) mengartikan partisipasi politik sebagai kegiatan seseorang/kelompok untuk ikut serta aktif dalam memilih pemimpin negara dan secara langsung/tidak langsung mempengaruhi kebijakan pemerintah (public policy).

Keempat melakukan sosialisasi politik sebagai suatu proses perkembangan seseorang untuk mendapatkan orientasi-orientasi politik dan pola-pola tingkah laku. Sosialisasi politik sebagai proses perubahan perilaku yang berhubungan erat dengan proses belajar memahami peristiwa politik (Alexis Tan dalam Harun \& Sumarno,2006:82). 
Kelima melakukan pendidikan politik, yakni usaha menanamkan, mengubah atau mempertahankan sistem nilai atau orientasi politik dengan mengaktifkan proses sikap, perilaku, sistem berpikir, serta pandangan seseorang atau kelompok, baik kader simpatisan maupun masyarakat umum yang dilakukan oleh politikus, profesional, dan aktivis atau lembaga/organisasi seperti partai politik (Hikmat,2010:41).

Keenam melakukan rekruitmen politik, yakni sebagai usaha untuk mengajak individuindividu ke dalam orientasi dan nilai politik yang pada akhirnya menjadikan sebagai anggota politik, baik sebagai simpatisan, kader, maupun pengurus organisasi politik.

Dengan dipandu keenam tujuan tersebut, DPRD harus menyusun strategi diseminasi informasi. Dalam konteks lembaga politik, banyak sekali strategi yang dapat dilakukan oleh DPRD. Namun, strategi yang paling banyak dilakukan, terutama oleh lembaga politik, adalah strategi persuasi. Hal itu berangkat dari fakta bahwa DPRD adalah lembaga wakil rakyat yang harus dapat mengayomi rakyat. Proses kelahirannya yang melalui pase-pase demokrasi lebih menjunjung musyawarah dan kesetaraan bukan aspek dominasi kekuasaan. Oleh karena itu, cara-cara doktrinisasi, paksaan, dan sikap-sikap yang menempatkan rakyat sebagai objek harus dihindarkan.

Salah satu model strategi yang tergolong sering digunakan lembaga politik adalah yang disarankan Hugh Rank (dalam Pawito, 2009: 261) yang pada intinya melibatkan dua komponen pokok, yakni: (a) Mengekspose secara intensif ide-ide, peristiwa, kegiatan atau substansi diseminasi informasi lainnya yang bernilai kebaikan-kebaikan dan kelebihan-kelebihan (sisi positif) yang ada pada DPRD. (b) Memainkan, menyamarkan, atau menyembunyikan (downplay) aspekaspek sisi negatif.

Untuk menguatkan strategi tersebut, Parwito (2009:262) menyodorkan taktis persuader dengan mengambil teknik-teknik pengulangan, asosiasi, dan komposisi untuk kepentingan ekspose (intensify) sisi positif dan teknik penghilangan, mengubah, dan mengaburkan sisi negatif. Namun, yang tidak dapat diadopsi dari strategi Hugh Rank adalah upaya "perlawanan" terhadap pesaing karena dalam konteks lembaga Legislatif Daerah sebagai wakil rakyat tidak "memiliki" lawan secara langsung. Keberadaan eksekutif sebagaimana amanah UU No. 32 Tahun 2004 adalah mitra, kawan, dan bukan lawan.

Namun demikian, mengekspos kegiatan bernilai positif bukan berarti mengabaikan aspek-aspek hummant interest sebagai upaya persuasi yang lebih menarik rakyat. Ide, peristiwa, kegiatan, dan bahan-bahan diseminasi informasi lainnya yang berkategori menarik harus tetap menjadi rujukan, seperti, hal konkret, suspense, konflik, popularitas, baru dan eksotik, sensasional logik, aktual, kata beraroma, kalimat beragam, anekdot, fakta mengejutkan, ramalan, humor, serta yang berhubungan dekat dengan orang, tempat, atau peristiwa lokal.

Jalaluddin Rachmat

(2006:115)

menyodorkan prinsip-prinsip yang dapat dipertimbangkan dalam memilih bahan persuasi, seperti dalam diseminasi informasi, yakni: 1. Tunjukkan bahwa topik berhubungan erat dengan kepentingan khalayak; 2. Hindari satu jenis teknik pengembangan bahasan; 3. Gunakan contohcontoh yang spesifik dan konkret; 4. Ceritakan kisah-kisah menarik; 5. Organisasikan bahan-bahan atau berikan makna secara orisinal, kreatif, dan informatif.

Selain itu, langkah teknis yang harus dilakukan dalam mengoptimalkan diseminasi informasi kinerja DPRD adalah sebagai berikut;

1. Mengolah pesan.

Pesan sebagai fenomena yang berjalan pada rute perputarannya pada suatu saluran yang menghubungkan dua sumber/penerima atau lebih. Suatu pesan ditrasformasikan pada titik-titik penyandian dan pengalihan sandi, sehingga pesan merupakan pikiran atau 
ide pada suatu tempat pada sistem jaringan syaraf (neurophysiological) dari sumber/penerima dan setelah penyandian terjadi dalam suatu situasi tatap muka, ditransformasikan ke dalam rangkaian getaran udara dan sinar-sinar cahaya yang terpantulkan (Fisher,1986:364).

Dalam proses komunikasi politik, pesan politik merupakan komponen terpenting. Pesan politik itu adalah pesan yang dibawa oleh komunikator politik, baik dalam bentuk gagasan, pikiran, ide, pesaraan, sikap, maupun perilaku tentang politik yang mempengaruhi komunikan politik.

Graber (1984:138) memandang bahwa pesan komunikasi politik dalam perspektif yang sangat luas. Menurutnya, pesan komunikasi politik dapat berupa kebiasaan-kebiasaan (custom), aturanaturan (rules), struktur, dan faktor-faktor lingkungan yang berpengaruh terhadap kehidupan politik. Bahkan, Muhtadi (2008: 11) menegaskan bahwa pesan komunikasi politik itu adalah seluruh budaya politik yang berkembang di suatu negara.

2. Memilih Komunikator

Seperti halnya perspektif komunikasi secara umum, komunikator politik dapat dikategorikan sebagai pemberi pesan politik. Pengkategorian ini berangkat dari perspektif umum bahwa komunikasi politik adalah proses penyampaian pesan politik dari komunikator politik kepada komunikan politik. Oleh karena itu, banyak ilmuwan yang mengkaji komunikasi politik memberikan istilah baku bagi pemberi pesan politik dengan istilah komunikator politik, seperti, yang diungkapkan Ali (1999:35) untuk menilai lemahnya komunikasi politik di Indonesia, ia menyebutkan karena peran-peran komunikator politik di lembaga eksekutif yang terlalu dominan.

Dan Nimmo (2001:126) mengutif pemikiran L.W. Dobb yang mengkualifikasikan komunikator infrastruktur ke dalam tiga kategori yaitu para politikus, profesionalis dan aktivis. Siapapun kategori komunikator, setidaknya ada tiga kualifikasi yang harus dipenuhi oleh komunikator yang tepat, yakni Expertise (memiliki keahlian), Trustworthiness (dipercaya), Atractiveness (menarik).

3. Memetakan Isue

Terdapat tiga kategori yang menjadi sumber isue, yakni media massa, mitra (horizontal dan vertikal), dan oponi publik yang beredar di masyarakat. Untuk diseminasi informasi harus dipetakan mana isue yang relevan dan tidak relevan, mana isue yang berpengaruh dan yang tidak. Hal itu diperlukan untuk dijadikan rujukan dalam mencounter isue.

4. Memetakan Sasaran/Khalayak

Komponen terpenting juga dalam proses komunikasi adalah komunikan atau penerima pesan. Menurut Effendy (2001:13), komunikan memiliki fungsi mengawa-sandi (decode) pesan dari komunikator, sehingga komunikan disebut decoder. Selain itu, komunikan pun dapat memberikan umpan balik (feedback) sebagai tanggapan atas pesan yang disampaikan kepadanya. Feedback itu dapat berbentuk langsung atau umpan balik seketika (immediate feedback), misalnya dalam komunikasi antarpersona (face to face communication) atau bisa juga feedback itu bersifat tertunda (delayed feedback), misalnya dalam komunikasi bermedia dengan menggunakan media surat kabar atau majalah, sedangkan menggunakan media elektronik seperti televisi dan radio sekarang dapat terjadi immediate feedback karena kecanggihan teknologi informasi.

Sasaran diseminasi informasi bagi DPRD adalah khalayak/rakyat pemilih. Agar diseminasi informasi efektif diperlukan upaya untuk mengenalnya, baik dari sisi bahasa yang dikuasasi, tingkat kecerdasan dan daya kritis, sifat mudah percaya atau tidak, media yang 
banyak digunakan, maupun tokoh atau figur yang berpengaruh (dihormati dan didengar).

5. Memilih Media

Yang juga sangat penting dalam diseminasi informasi adalah memilih media yang dapat digunakan dengan prinsip informasi sampai kepada khalayak dengan efisien dan efektif. Termasuk di dalamnya memastikan alternatif saluran/media yang tepat : Saluran kelembagaan (Bakohumas), saluran interpersonal (Seminar, lokakarya, dll), media tradisional (pertunjukan rakyat), media massa (cetak dan siaran), media sosial (Website, portal, blog, jejaring sosial), kelompok strategis (KIM, Ormas, LSM), media luar ruang dan cetakan (spanduk, poster, stiker, kalender, banner, dll).

6. Memilih endorser/nara sumber

Nara sumber yang baik setidaknya dapat memenuhi empat kategori, yakni: 1) Attractive (memiliki fisik yang baik atau menarik dan psikis yang matang); 2) Knowledge (penguasaan keilmuan yang baik sesuai dengan keinginan/pesanan); 3) Trusthy (memiliki kharisma yang besar dan reputasi positif di mata publik); 4) Powerfull (punya kekuatan massa sebagai opinion leader.

7. Memilih waktu dan frekuensi

Diseminasi informasi yang efektif dan efisien di antaranya karena dapat memilih waktu, baik dalam pemilihan hari \& bulan, pagi, siang, malam, hari kerja atau libur dan seterusnya. Hal itu penting karena setiap waktu memiliki karakter masing-masing. Begitu juga frekuensi diseminasi informasi, terutama jika dilakukan di media massa, mulai dari kolom yang digunakan, banyaknya kali terbit, durasi tayangan, sampai perlu tidaknya bloking time, dan seterusnya.

8. Menangkap Respon

Bagian dari langkah strategi diseminasi informasi yang tidak kalah juga pentingnya adalah menangkap respon karena respon adalah sumber inspirasi untuk melakukan evaluasi dan menakar tingkat keberhasilan diseminasi informasi. Banyak teknik menangkap respon dari khalayak yang dapat dilakukan, seperti, survei, pooling, wawancara, angket, kotak saran, informasi media massa, dan sebagainya.

Beranjak dari paparan strategi diseminasi informasi kinerja DPRD tersebut, dapat digambarkan model diseminasi informasi alternatif bagi DPRD sebagai berikut:

\section{Model Alternatif Diseminasi Informasi Lembaga Legislatif Daerah}

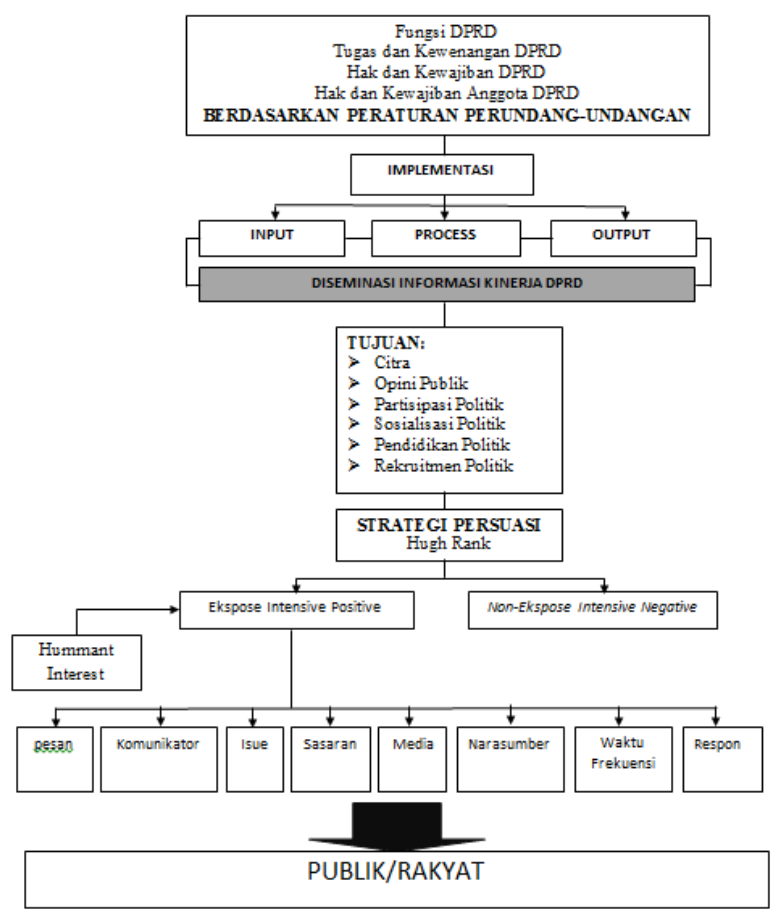

\section{Kesimpulan dan Rekomendasi}

\section{Kesimpulam}

Berdasarkan pemaparan analisis dan pembahasan di atas sebelumnya, maka dapat ditarik simpulan sebagai berikut:

1. Banyak peraturan perundang-undangan yang terkait dengan lembaga Legislatif Daerah yang mengamanahkan urgensi diseminasi informasi kinerja DPRD sebagai bagian dari pertanggungjawaban 
publik dan merupakan bagian penting dari penguatan kualitas demokrasi di daerah.

2. Semua kegiatan, dari mulai input, process, sampai output yang dilakukan DPRD, baik sebagai lembaga Legislatif Daerah maupun sebagai anggota DPRD, dalam implementasi amanah peraturan perundang-undangan yang terkait dengan fungsi, tugas dan wewenang, hak dan kewajiban, serta hal lainnya merupakan hal penting untuk didiseminasikan kepada publik, kecuali informasi yang harus dirahasiakan menurut peraturan perundang-undangan.

3. Salah satu model alternatif diseminasi informasi kinerja lembaga Legislatif Daerah dalam optimalisasi penguatan kualitas demokrasi di daerah adalah Model Persuasi Hugh Rank yang lebih menguatkan pelibatan komponen pokok, mengekspose secara intensif ide-ide, peristiwa, kegiatan atau substansi diseminasi informasi lainnya yang bernilai kebaikan dan kelebihan (sisi positif) yang ada pada DPRD serta memainkan, menyamarkan, atau menyembunyikan (downplay) aspek-aspek sisi negatif.

\section{Rekomendasi}

Berdasarkan pemaparan analisis, pembahasan, dan simpulan di atas dapat disampaikan saran-saran sebagai berikut:

1. Semua kegiatan, mulai dari input, process, dan output, yang dilakukan lembaga Legislatif Daerah yang terkait dengan fungsi, tugas dan wewenang, hak dan kewajiban DPRD harus didiseminasikan kepada publik sesuai dengan tingkat urgensinya;

2. DPRD sebagai lembaga Legislatif Daerah harus melakukan pemilahan informasi dalam kategori informasi yang terbuka dan tertutup dengan merujuk pada peraturan perundang-undangan;

3. Seluruh informasi terbuka yang ada dan dikuasai DPRD sebagai lembaga Legislatif Daerah harus masuk pada program diseminasi informasi kinerja melalui sarana publikasi yang varian, baik dalam bentuk media massa, media sosial, medio outdor, maupun media lainnya;

4. Teknik penyajian diseminasi informasi kinerja lembaga Legislatif Daerah dapat menggunakan Model Persuasi Hugh Rank yang lebih menguatkan pelibatan komponen pokok mengekspose secara intensif ide-ide, peristiwa, kegiatan yang bernilai kebaikan dan kelebihan (sisi positif) serta memainkan, menyamarkan, atau menyembunyikan (downplay) aspekaspek sisi negatif;

5. Substansi diseminasi informasi yang disajikan DPRD sebagai lembaga Legislatif Daerah harus pula mempertimbangkan aspek-aspek hummant interest, sehingga sampai kepada publik sesuai harapan sasaran.

\section{Daftar Pustaka}

Amy Gutmann dan Dennis Thompson, Why Deliberative Democracy?, (Princeton, NJ: Princeton University Press,2004: Dalam Surbakti,2008

Benyamin Barber, 1984. Strong Democracy, Participatory Politics for a New Age. Berkeleh, CA: University of California Press

DPRD Provinsi Jawa Barat. Profil DPRD Provinsi Jawa Barat Periode 20092014. Sekretariat DPRD Jawa Barat 2013

Dwiyanto, Agus dkk.2002. Reformasi Birokrasi Publik di Indonesia. Jogjakarta: Pusat Studi Kependudukan dan Kebijakan Universitas Gajah Mada

Effendy, Onong Uchjana. 2000. Ilmu Komunikasi, Teori dan Praktek. Bandung: Remaja Rosda Karya

Fisher, B. Aubrey. 1986. Teori-Teori Komunikasi. Bandung: Remadja Karya

Graber, Doris A.: 1984. Processing the News: How People Tame the Information. New York 
Hadi, AG Sutriyanto. Analisis Kinerja DPRD Jawa Tenggah Periode 1999-2004. Tesis Program Pasca Sarjana Universitas Diponogoro:2004

Harun, Rochajat dan Sumarno A.P. 2006. Komunikasi Politik. Bandung: Mandar Maju

Hikmat, Mahi M. 2010. Komunikasi Politik: Teori dan Praktek. Bandung: Simbiosa Rekatama Media

Joseph A. Schumpeter, Capitalism, Socialism, and Democracy. 2d ed. (New York: Harper, 1947. H. 129 dan Samuel P. Huntington, The Third Wave: Democratization in the Late Twentieth Century, (norman, Ok: University of Oklahoma Press, h. 6-10: dalam Surbakti:2008

Keban, Yeremias T.1995. Indikator Kinerja Pemerintah Daerah: Pendekatan Manajemen dan Kebijakan. Jogjakarta: Fisipol UGM

Muhtadi, Asep saeful. 2002. Dinamika Komunikasi Politik NU. Disertasi. Bandung: PPS Unpad

Nimmo, Dan D., 1989. Komunikasi Politik, terjemahan Tjun Surjaman, Bandung: Remadja Rosdakarya

Parwito. 2009. Komunikasi Politik, Media Massa, dan Kampanye Pemilihan. Yogyakarta: Jalasutra

Robert Dahl. Democracy and Its Critic (New Haven, NJ: Yale University Press. 1989)

Ruky, S. Ahmad. 2002. Sistem Manajemen Kinerja. Jakarta: PT Gramedia

Syafrudin, Ateng. 2001. DPRD dan Kepala Daerah dalam Bentuk dan Susunan Pemerintahan Daerah Menurut UU No. 22 Tahun 1999. Bandung: STPDN

Sumo, Bambang P. 1999. Strategi Diseminasi Informasi Gerakan KB Nasional. Rapat Anggota Jaringan Informasi dan Dokumentasi di Gedung Perpustakaan Fak. Ekonomi UI, 24 November 1999

Surbakti, Ramlan. 2008. Pemilu untuk Pembangunan Tata Politik Demokratis. Kemitraan bagi Pembaharuan Tata Pemerintahan 